\title{
An easy protocol for the domino synthesis of diversely functionalized spirocarbocycles and their biological evaluation
}

\author{
SELVARANGAM E KIRUTHIKA ${ }^{\mathrm{a}}$, PARAMASIVAN T PERUMAL ${ }^{\mathrm{a}, *}$, C BALACHANDRAN $^{\mathrm{b}}$ \\ and S IGNACIMUTHU \\ ${ }^{a}$ Organic Chemistry Division, CSIR-Central Leather Research Institute, Adyar, Chennai 600 020, India \\ ${ }^{b}$ Division of Microbiology, Entomology Research Institute, Loyola College, Chennai 600 034, India \\ e-mail: ptperumal@gmail.com
}

MS received 16 June 2013; revised 17 October 2013; accepted 18 October 2013

\begin{abstract}
A base-catalysed domino reaction for the synthesis of spirocarbocycles in excellent yields using chalcones and vinyl malononitriles is reported. This consists of a series of steps including Knoevenagel condensation followed by intermolecular vinylogous Michael addition and intramolecular cyclization. The synthesized compounds were evaluated for their antimicrobial activity and the compounds exhibited moderate to excellent activities.
\end{abstract}

Keywords. Spirocarbocycles; L-proline; vinyl malononitriles; chalcones; antimicrobial activity.

\section{Introduction}

Carbon-carbon and carbon-heteroatom bond forming reactions play a crucial role in organic synthesis. Synthesis of diversely functionalized molecules from simple starting materials which fulfils both economic and environmental aspects together is a great challenge to organic chemists. ${ }^{\text {1a }}$ Multicomponent reactions (MCRs) which involve domino processes assist in achieving this ideal goal. ${ }^{1}$ MCRs often do not require the usage of expensive catalysts, tedious protection and deprotection processes, purification and isolation procedures. ${ }^{2}$ Hence, MCRs are of growing importance in the construction of diversely functionalized heterocycles. ${ }^{3}$

Development of efficient methods to construct spiro compounds has been a topic of great relevance in organic synthesis due to their pronounced biological importance as they are used as anticancer agents, ${ }^{4}$ antibacterial agents, ${ }^{5}$ anticonvulsant agents, ${ }^{6}$ antituberculosis agents, ${ }^{7 a}$ etc. ${ }^{7}$ Methodologies for the synthesis of spirocyclic compounds range from the classical approaches involving [3+2] cycloadditions ${ }^{8}$ to the recently emerging transition metal-based processes. ${ }^{9}$ Their synthesis also includes other protocols such as ring closure methodologies, ${ }^{10}$ radical cyclizations, ${ }^{11}$ cleavage of bridged ring systems, etc. ${ }^{12}$ Such diverse spirocycles are characterized by a spiro ring fusion with varied heterocyclic motifs. ${ }^{13}$ Among the various heterocyclic motifs, isoxazol-5-ones and oxindole moieties

\footnotetext{
*For correspondence
}

have proven to be valuable intermediates for the construction of spirocarbocycles due to their importance in both synthesis and pharmacology. ${ }^{14,15}$

Biological importance of these privileged medicinal scaffolds possessing a spiro ring fusion led us to the synthesis of spirocarbocycles. As a continuation of our research work devoted to the development of multicomponent domino reactions, ${ }^{16}$ we would herein like to report the synthesis of spirocarbocycles utilizing basecatalysed multicomponent domino reactions involving chalcones and vinyl malononitriles along with biological evaluation of the synthesized compounds.

\section{Experimental}

\subsection{Materials, methods and instruments}

Melting points were determined on Gallenkamp melting point apparatus and are uncorrected. Infrared (IR) spectra were recorded on a Perkin-Elmer FTIR spectrophotometer as $\mathrm{KBr}$ pellets. ${ }^{1} \mathrm{H}$ and ${ }^{13} \mathrm{C}$ NMR spectra were obtained in DMSO- $d_{6}$ on a JEOL spectrometer at 500 and $125 \mathrm{MHz}$, respectively. Proton chemical shifts $(\delta)$ are relative to tetramethylsilane (TMS, $\delta=0.00$ ) as internal standard and expressed in parts per million. The number of protons $(n)$ for a given resonance was indicated as $n \mathrm{H}$. Coupling constants $(J)$ are given in hertz. Spin multiplicities are given as s (singlet), $\mathrm{d}$ (doublet), $\mathrm{t}$ (triplet) and $\mathrm{m}$ (multiplet). Mass spectra were recorded on a Thermo Finnigan LCQ Advantage MAX 6000 
ESI mass spectrometer and Perkin-Elmer GC-MS. Elemental analyses were recorded using a Thermo Finnigan FLASH EA 1112CHN analyser. All the compounds gave $\mathrm{C}, \mathrm{H}$ and $\mathrm{N}$ analysis within $\pm 0.5 \%$ of the theoretical values. Analytical TLC was performed on precoated plastic sheets of silica gel G/UV-254 of $0.2 \mathrm{~mm}$ thickness (Macherey-Nagel, Germany) using analytical grade solvents and visualizing with UV light $(\lambda=254$ and $365 \mathrm{~nm}$ ).

\subsection{Experimental procedure for the synthesis of $\mathbf{4 a}-\boldsymbol{l}$}

3-Phenyl-5-isoxazolone $\mathbf{1}$ (1 mmol), aldehhydes $\mathbf{2 a - k}$ were stirred in a mixture of EtOH: $\mathrm{H}_{2} \mathrm{O}(2: 1)$ in the presence of L-proline $(15 \mathrm{~mol} \%)$ for $10 \mathrm{~min}$ followed by the addition of alkylidene malononitrile $\mathbf{3 a}-\mathbf{c}(1 \mathrm{mmol})$ at room temperature for $1 \mathrm{~h}$. The solid precipitated out was filtered off and purified by recrystallization from methanol to afford product $\mathbf{4 a}-\mathbf{l}$ as white crystalline solid.

2.2a Spectral data for a representative compound $4 a$ : White solid. mp: $152-154^{\circ}$ C. $v_{\max }(\mathrm{KBr}): 3345,3224$, 2926, 2860, 2207, 1790, 1640, 1593, 1514, 1446, 1393, $1151,908,881,764,691,640 \mathrm{~cm}^{-1} .{ }^{1} \mathrm{H}$ NMR (DMSO$\left.d_{6}, 500 \mathrm{MHz}\right): \delta 0.74(\mathrm{q}, 1 \mathrm{H}, J=9 \mathrm{~Hz}), 1.25(\mathrm{~m}, 1 \mathrm{H})$, $1.40(\mathrm{~m}, 1 \mathrm{H}), 1.62(\mathrm{~m}, 1 \mathrm{H}), 2.07(\mathrm{~m}, 1 \mathrm{H}), 2.17(\mathrm{~m}, 1 \mathrm{H})$, $2.22(\mathrm{~s}, 3 \mathrm{H}), 3.06(\mathrm{~d}, 1 \mathrm{H}, J=12.5 \mathrm{~Hz}), 3.18(\mathrm{~m}, 1 \mathrm{H})$, $5.76(\mathrm{~m}, 1 \mathrm{H}), 6.14(\mathrm{~d}, 1 \mathrm{H}, J=8.5 \mathrm{~Hz}), 6.60(\mathrm{bs}, 2 \mathrm{H}$, $-\mathrm{NH}_{2}, \mathrm{D}_{2} \mathrm{O}$ exchangeable), $6.86(\mathrm{~d}, 1 \mathrm{H}, J=7.5 \mathrm{~Hz})$, $7.05(\mathrm{~d}, 1 \mathrm{H}, J=8 \mathrm{~Hz}), 7.16(\mathrm{~d}, 1 \mathrm{H}, J=8.5 \mathrm{~Hz})$, 7.59 (m, 5H). ${ }^{13} \mathrm{C}$ NMR (DMSO-d $6,125 \mathrm{MHz}$ ): $\delta 20.6$, 21.5, 25.0, 27.4, 31.3, 50.1, 59.1, 82.1, 117.1, 119.2, $125.6,126.4,126.7,128.6,129.5,129.6,130.3,130.7$, 131.5, 132.3, 137.6, 147.6, 164.3, 176.1 MS (m/z): 410 $(\mathrm{M}+\mathrm{H})^{+}$. Anal. Calcd. for $\mathrm{C}_{26} \mathrm{H}_{23} \mathrm{~N}_{3} \mathrm{O}_{2}$ : C, 76.26; H, 5.66; N, 10.26. Found: C, 76.24; H, 5.67; N, 10.27.

\subsection{Experimental procedure for the synthesis of $\mathbf{6} \boldsymbol{a}-\boldsymbol{e}$}

3-(2-Oxo-2-phenylethylidene)indolin-2-one1 5 (1 mmol) and alkylidene malononitrile $\mathbf{3 a}-\mathbf{e}(1 \mathrm{mmol})$ were stirred in a mixture of EtOH: $\mathrm{H}_{2} \mathrm{O}(2: 1)$ in the presence of L-proline $(15 \mathrm{~mol} \%)$ at room temperature for $3 \mathrm{~h}$. The solid precipitated out was filtered off and recrystallized from methanol to afford product $\mathbf{6 a - e}$ as a white solid.

2.3a Spectral data for a representative compound $\boldsymbol{6} \boldsymbol{b}$ : White solid. mp: $212-214^{\circ}$ C. $v_{\max }(\mathrm{KBr}): 3433,3351$, 3305, 3059, 2930, 2828, 2200, 1708, 1669, 1633, 1575,
1473, 1395, 1212, 755, $626 \mathrm{~cm}^{-1} .{ }^{1} \mathrm{H}$ NMR (DMSO$\left.\mathrm{d}_{6}, 500 \mathrm{MHz}\right): \delta 0.96(\mathrm{q}, 1 \mathrm{H}, J=12.0 \mathrm{~Hz}), 1.21(\mathrm{~m}$, $1 \mathrm{H}), 1.14(\mathrm{~m}, 1 \mathrm{H}), 1.33(\mathrm{~m}, 1 \mathrm{H}), 1.63(\mathrm{~m}, 1 \mathrm{H}), 2.07(\mathrm{~m}$, $1 \mathrm{H}), 3.41(\mathrm{~m}, 2 \mathrm{H}), 4.40(\mathrm{~d}, 1 \mathrm{H}, J=12.5 \mathrm{~Hz}), 5.42(\mathrm{~s}$, $2 \mathrm{H},-\mathrm{NH}_{2}, \mathrm{D}_{2} \mathrm{O}$ exchangeable), $5.56(\mathrm{~m}, 1 \mathrm{H}), 6.71(\mathrm{~m}$, $2 \mathrm{H}), 7.03(\mathrm{t}, 1 \mathrm{H}, J=7.5 \mathrm{~Hz}), 7.36(\mathrm{t}, 3 \mathrm{H}, J=7.5 \mathrm{~Hz})$, $7.50(\mathrm{t}, 1 \mathrm{H}, J=8 \mathrm{~Hz}), 7.80(\mathrm{~d}, 1 \mathrm{H}, J=8.5 \mathrm{~Hz}), 10.57$ (s, $1 \mathrm{H},-\mathrm{NH}, \mathrm{D}_{2} \mathrm{O}$ exchangeable). ${ }^{13} \mathrm{C}$ NMR (DMSO$\left.\mathrm{d}_{6}, 125 \mathrm{MHz}\right): \delta 14.3,21.8,24.9,27.5,32.7,52.0,54.1$, $60.0,81.0,110.0,116.7,118.2,121.8,124.9,127.3$, 128.3, 128.8, 129.6, 131.7, 133.7, 137.7, 143.2, 154.4, 176.0, 200.5. MS $(\mathrm{m} / \mathrm{z}): 396(\mathrm{M}+\mathrm{H})^{+}$. Anal. Calcd. for $\mathrm{C}_{25} \mathrm{H}_{21} \mathrm{~N}_{3} \mathrm{O}_{2}$ : C, 75.93; H, 5.35; N, 10.63. Found: C, $75.91 ; \mathrm{H}, 5.36$; N, 10.64 .

\subsection{Biological evaluation}

2.4a Antimicrobial activity: Antimicrobial activities were carried out using disc diffusion method. ${ }^{17}$ Petri plates were prepared with $20 \mathrm{ml}$ of sterile Mueller Hinton agar (MHA) (Hi-media, Mumbai). The test cultures were swabbed on the top of the solidified media and allowed to dry for $10 \mathrm{~min}$ and a specific amount of synthesized compound at $1 \mathrm{mg}$ /disc was added to each disc separately. The loaded discs were placed on the surface of the medium and left for $30 \mathrm{~min}$ at room temperature for compound diffusion. Negative control was prepared using respective solvents. Streptomycin was used as positive control against bacteria. Ketoconazole was used as positive control for fungi. The plates were incubated for $24 \mathrm{~h}$ at $37^{\circ} \mathrm{C}$ for bacteria and for $48 \mathrm{~h}$ at $28^{\circ} \mathrm{C}$ for fungi. Zones of inhibition were recorded in millimetres and the experiment was repeated twice. Bacterial inocula were prepared by growing cells in Mueller Hinton broth (MHB) (Himedia) for $24 \mathrm{~h}$ at $37^{\circ} \mathrm{C}$. Filamentous fungi were grown on Sabouraud dextrose agar (SDA) slants at $28^{\circ} \mathrm{C}$ for 10 days and the spores were collected using sterile doubled distilled water and homogenized. Yeast was grown on Sabouraud dextrose broth (SDB) at $28^{\circ} \mathrm{C}$ for $48 \mathrm{~h}$.

2.4b Minimum inhibitory concentration: Minimum inhibitory concentration (MIC) studies of the synthesised compounds were performed according to the standard reference methods for bacteria, ${ }^{18}$ for filamentous fungi ${ }^{19}$ and yeasts. ${ }^{20}$ Required concentrations $(1000,500,250,125,62.5,31.25,15.62 \mu \mathrm{g} / \mathrm{mL}$ and $7.81 \mu \mathrm{g} / \mathrm{mL}$ ) of the compound were dissolved in DMSO $(2 \%)$, and diluted to give serial two-fold dilutions that were added to each medium in 96 well plates. An inoculum of $100 \mu \mathrm{L}$ from each well was inoculated. Antifungal agents such as Ketoconazole for fungi and 


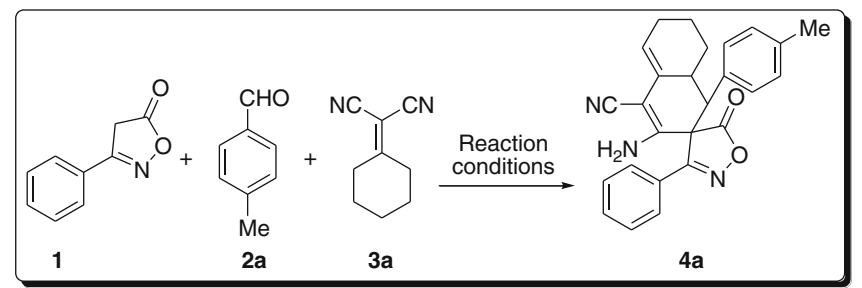

Scheme 1. Synthesis and screening of reaction conditions for $\mathbf{4 a}$.

Streptomycin for bacteria were included in the assays as positive controls. For fungi, the plates were incubated for 48 to $72 \mathrm{~h}$ at $28^{\circ} \mathrm{C}$ and for bacteria the plates were incubated for $24 \mathrm{~h}$ at $37^{\circ} \mathrm{C}$. The MIC for fungi was defined as the lowest extract concentration, showing no visible fungal growth after incubation time. $5 \mu \mathrm{L}$ of tested broth was placed on the sterile MHA plates for bacteria and incubated at respective temperatures. The MIC for bacteria was determined as the lowest concentration of the compound inhibiting visual growth of the test cultures on the agar plate.

\section{Results and discussions}

\subsection{Chemistry}

In our investigatory experiment, 3-phenyl-5-isoxazolone 1, 4-methyl benzaldehyde $\mathbf{2 a}$ and cyclohexylidene malononitrile 3a were stirred to afford the product 4a under various reaction conditions viz. solvents, temperature, base catalysts and adding sequence of substrates (scheme 1, table 1).

The onset of the uncatalysed model reaction in ethanol to afford the product $\mathbf{4 a}$ in a low yield of $45 \%$ (table 1, entry 1) prompted us to explore the optimum base catalyst for the reaction by using a range of base catalyst promoters (pyrrolidine, L-proline, DABCO, triethylamine, etc.) (table 1, entries 2-8). The reaction afforded comparatively better yields when L-proline was used as a base catalyst (table 1, entry 8). With the best catalyst L-proline, the reaction was performed in various solvents which included THF, DMF, $\mathrm{MeOH}$, water, etc. (table 1, entries 9-15). The reaction was also found to proceed under neat conditions (table 1, entry 14 ), but the completion was observed only after prolonged hours with a diminished yield of $40 \%$. In case of L-proline as the base catalyst, a slight increase in the stoichiometry altered the yield from $85 \%$ to $87 \%$ (table 1, entry 16). Further increase had no impact on the yield of the reaction (table 1, entry 17). The adding sequence of substrates also influenced the product

Table 1. Screening of solvents and base catalysts for the synthesis of $\mathbf{4 a}$.

\begin{tabular}{|c|c|c|c|c|c|}
\hline Entry & Solvent & Base Catalyst $^{\mathrm{a}}$ & Conditions & Time $(\mathrm{h})$ & Yield $(\%)^{\mathrm{b}}$ \\
\hline 1 & $\mathrm{EtOH}$ & - & $\mathrm{rt}$ & 10 & 45 \\
\hline 2 & EtOH & Pyrrolidine & $\mathrm{rt}$ & 5 & 67 \\
\hline 3 & $\mathrm{EtOH}$ & DBU & Reflux & 24 & 58 \\
\hline 4 & $\mathrm{EtOH}$ & $\mathrm{NEt}_{3}$ & $\mathrm{rt}$ & 10 & 59 \\
\hline 5 & $\mathrm{EtOH}$ & $\mathrm{K}_{2} \mathrm{CO}_{3}$ & $\mathrm{rt}$ & 2.5 & 62 \\
\hline 6 & EtOH & $\mathrm{NEt}_{3}$ & $\mathrm{rt}$ & 4 & 60 \\
\hline 7 & $\mathrm{EtOH}$ & $\mathrm{DABCO}$ & Reflux & 8 & 66 \\
\hline 8 & EtOH & L-Proline & $\mathrm{rt}$ & 3 & 75 \\
\hline 9 & $\mathrm{MeOH}$ & L-Proline & $\mathrm{rt}$ & 3 & 60 \\
\hline 10 & THF & L-Proline & $\mathrm{rt}$ & 8 & 65 \\
\hline 11 & $\mathrm{H}_{2} \mathrm{O}$ & L-Proline & $\mathrm{rt}$ & 9 & 75 \\
\hline 12 & $\mathrm{EtOH}: \mathrm{H}_{2} \mathrm{O}$ & L-Proline & $\mathrm{rt}$ & 1 & 85 \\
\hline 13 & $\mathrm{CH}_{3} \mathrm{CN}$ & L-Proline & $\mathrm{rt}$ & 5 & 68 \\
\hline 14 & - & - & $\mathrm{rt}$ & 48 & 40 \\
\hline 15 & DMF & L-Proline & $\mathrm{rt}$ & 6 & 55 \\
\hline 16 & EtOH: $\mathrm{H}_{2} \mathrm{O}$ & L-Proline & rt & 1 & $87^{\mathrm{c}}$ \\
\hline 17 & EtOH: $\mathrm{H}_{2} \mathrm{O}$ & L-Proline & $\mathrm{rt}$ & 1 & $86^{\mathrm{d}}$ \\
\hline
\end{tabular}

\footnotetext{
a All the reactions were performed using $10 \mathrm{~mol} \%$ of the base catalyst

${ }^{b}$ Isolated yield of $\mathbf{4 a}$ after recrystallization

c The reaction was performed using $15 \mathrm{~mol} \%$ of the catalyst

$\mathrm{d}$ The reaction was performed using $20 \mathrm{~mol} \%$ of the catalyst
} 


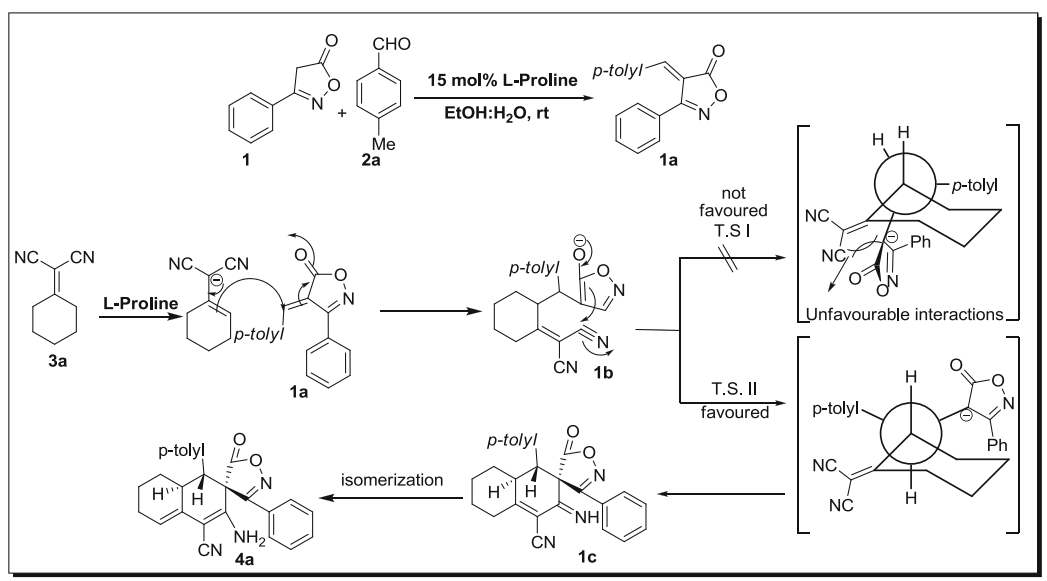

Scheme 2. Plausible mechanism for the formation of spirocarbocycle $\mathbf{4 a}$.

formation because the addition of 4-methyl benzaldehyde 2a to cyclohexylidene malononitrile $\mathbf{3 a}$ resulted in the formation of a pyran which reduced the yield of 4a. Hence, the best result (table 1, entry 16) was observed when 3-phenyl-5-isoxazolone 1 and 4-methyl benzaldehyde $\mathbf{2 a}$ were stirred for $10 \mathrm{~min}$ in the presence of $15 \mathrm{~mol} \%$ of L-proline in ethanol: water mixture ${ }^{21}$ at room temperature followed by the addition of cyclohexylidene malononitrile $\mathbf{3 a}$ to afford a precipitate which was filtered off and recrystallized from methanol to provide the product $\mathbf{4 a}$ in $87 \%$ yield.

A plausible mechanism to account for the formation of spirocarbocycle $\mathbf{4 a}$ is explained in scheme 2 . 3-Phenyl-5-isoxazolone $\mathbf{1}$ adds to 4-methyl benzaldehyde $\mathbf{2 a}$ with concomitant elimination of water leading to the formation of chalcone 1a. Alkylidene malononitrile 3a in the presence of L-proline undergoes intermolecular vinylogous Michael addition onto the activated double bond of chalcone 1a forming intermediate 1b. Among the two transition states TS I and TS II, the former suffers from unwanted steric interactions and congestions. Hence TS II of $\mathbf{1 b}$ undergoes intramolecular addition to the nitrile carbon resulting in the formation of a six membered spirocyclic intermediate 1c. The latter undergoes isomerization to provide the spirocarbocyclic diastereomer $\mathbf{4 a}$.

Having optimized the conditions, we expanded the scope of the reaction by varying the aldehyde and alkylidene malononitrile substrates. The reaction proceeded smoothly with aldehydes possessing electrondonating groups. Halogen substituents on the aldehyde (table 2, entries 2-4) did not have any pronounced effect on the yield of the products, but took longer duration for the completion of reaction than its counterparts having electron-rich substituents such as 4-methyl benzaldehyde and 3,4-dimethoxy benzaldehyde (table 2, entries 1 and 6). Various aldehydes including heterocyclic aldehydes were also explored (table 2, entries
7-12). Varying the ring size of the vinylogous alkylidene substrates (table 2, entries 1, 2 and 4) afforded the products in good yields. Thus, the reaction was found to be general and has a broad scope due to its applicability to a variety of substrates and the products 4a-1 were isolated in excellent yields $(75-87 \%)$ under milder reaction conditions. The results are summarized in table 2.

Structures of compounds $\mathbf{4 a}-\mathbf{l}$ were consistent with IR, ${ }^{1} \mathrm{H}$ and ${ }^{13} \mathrm{C}$ NMR, mass spectroscopy and elemental analysis data. The IR spectrum of $\mathbf{4 a}$ exhibited peaks at 2207 and $1790 \mathrm{~cm}^{-1}$ for the nitrile and lactone ester carbonyl groups, respectively. The ${ }^{1} \mathrm{H}$ NMR spectra of 4a showed a singlet at $\delta 6.60$ for the $-\mathrm{NH}_{2}$ protons $\left(\mathrm{D}_{2} \mathrm{O}\right.$ exchangeable). The signal at $\delta 82.1$ indicated the presence of spiro carbon in the ${ }^{13} \mathrm{C}$ NMR spectra. The mass spectra also exhibited a distinguishing peak at $\mathrm{m} / \mathrm{z}$ $410[\mathrm{M}+\mathrm{H}]^{+}$. Thus the above data confirms the formation of 4a. The structure was further confirmed by single crystal X-ray analysis performed for a representative compound $\mathbf{4 g}$ (figure 1 ). ${ }^{22}$ The stereochemistry was assigned based on ${ }^{1} \mathrm{H}$ NMR spectroscopy and Xray single crystal analysis. The ${ }^{1} \mathrm{H}$ NMR spectra for 4a exhibits a doublet for the $\mathrm{H}_{\mathrm{a}}$ proton which possesses coupling constant of $J=12.5 \mathrm{~Hz}$ characteristic of a trans relation between $\mathrm{H}_{\mathrm{a}}$ and $\mathrm{H}_{\mathrm{b}}$ protons. The $\mathrm{H}_{\mathrm{a}}$ and $\mathrm{H}_{\mathrm{b}}$ protons show trans relation with respect to each other which is clearly observed from the single crystal X-ray analysis of compound $\mathbf{4 g}$ which further supports the ${ }^{1} \mathrm{H}$ NMR spectroscopy. This shows that the reaction of 3-phenyl-5-isoxazolone 1 with aldehydes 2a-l and alkylidene malononitriles $\mathbf{3 a - c}$ is completely diastereoselective in affording only the trans diastereomer.

To extend the utility of this multicomponent reaction, studies were extended to other chalcones such as isatin chalcones under the same protocol which results in the formation of spiroxindoles. The reaction provided 
Table 2. Synthesis of spirocarbocycles $(\mathbf{4 a}-\mathbf{l})$.

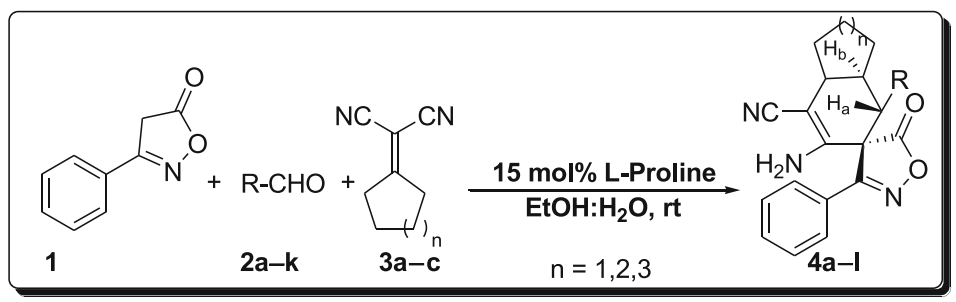

Entry Aldehyde

Alkylidene

Product

Time (h) malononitriles

Yield $(\%)^{[a]}$

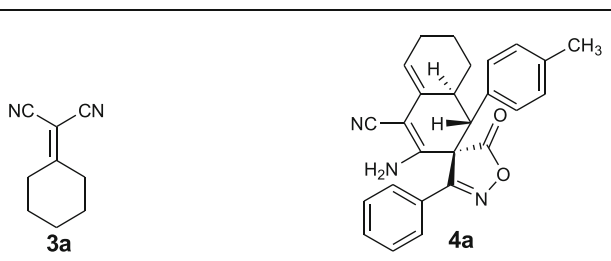

1

87

1
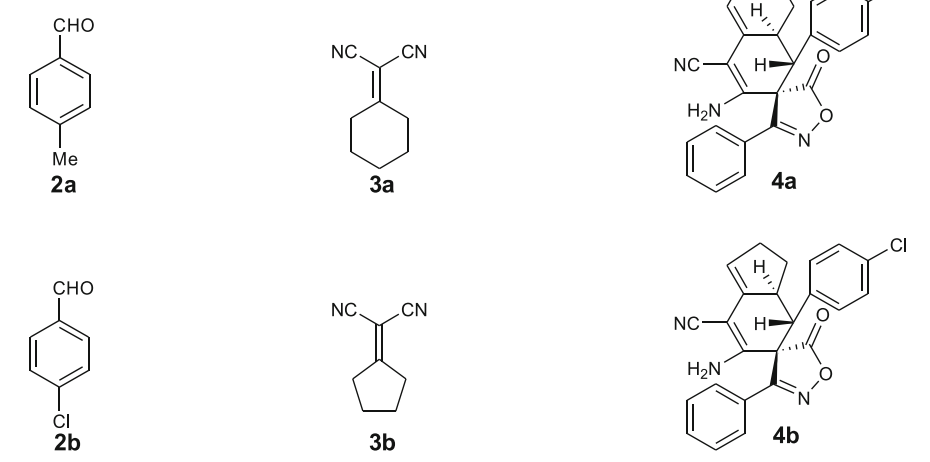

7

82

2

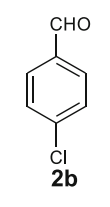<smiles>N#CC(C#N)=C1CC[C+]CC1</smiles><smiles>Cc1ccccc1C1=NOC(=O)[C@]12C(N)=C(C#N)C1=CCCC[C@H]1[C@H]2c1ccc(F)cc1</smiles>

3

81

4

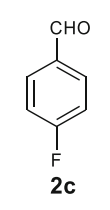<smiles>N#CC(C#N)=C1CCCCC1</smiles><smiles>N#CC1=C(N)C2(C(=O)COC2c2ccc(Cl)cc2)C(c2ccccc2)=NOC1=N</smiles>

10

80<smiles>COc1cc(Br)c(C=O)cc1OC</smiles><smiles>N#CC(C#N)=C1CC[CH]CC1</smiles>

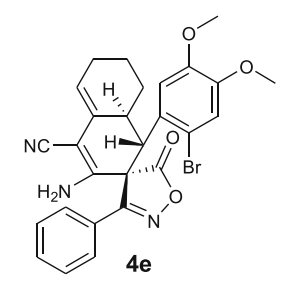<smiles>COc1ccc(C=O)cc1OC</smiles><smiles>N#CC(C#N)=C1CCCC1</smiles>

3b<smiles>[CH]=C(C1=C(N)C(C#N)=C2CCCC2C12C(=O)ON=C2c1ccc(OC)c(OC)c1)c1ccccc1</smiles>

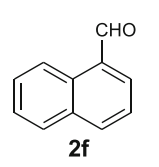<smiles>N#CC(C#N)=C1CC[C+]CC1</smiles>

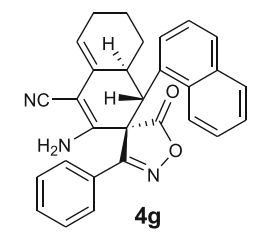


Table 2. (continued)

Entry Yield (\%) [a]

$\left[{ }^{a}\right]$ Isolated yield after recrystallization from methanol

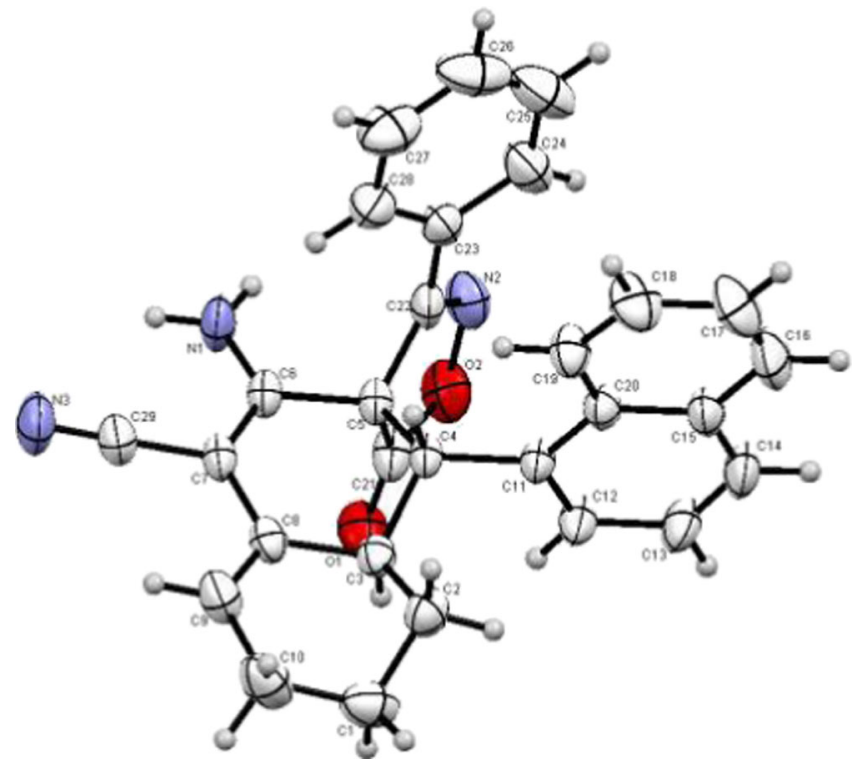

Figure 1. ORTEP diagram of $\mathbf{4 g}$. 
spiroxindoles in good yields (79-83\%) and the results are tabulated in table 3.

Structures of compounds $\mathbf{6 a - d}$ were consistent with IR, ${ }^{1} \mathrm{H}$ and ${ }^{13} \mathrm{C}$ NMR, mass spectroscopy and elemental analysis data. The IR spectrum of $\mathbf{6 b}$ exhibited peaks at 2200, 1708 and $1669 \mathrm{~cm}^{-1}$ for the nitrile, keto and amide carbonyls, respectively. The ${ }^{1} \mathrm{H}$ NMR spectra of 6b showed two singlets at $\delta 5.42$ and 10.57 for the
$-\mathrm{N} \mathrm{H}_{2}$ and $-\mathrm{NH}$ protons $\left(\mathrm{D}_{2} \mathrm{O}\right.$ exchangeable), respectively, clearly indicating the incorporation of both the moieties in the product. The doublet appearing for the $\mathrm{H}_{\mathrm{a}}$ proton of the product $\mathbf{6 b}$ shows a coupling constant value of $12.5 \mathrm{~Hz}$ indicative of the trans stereochemistry between the $\mathrm{H}_{\mathrm{a}}$ and $\mathrm{H}_{\mathrm{b}}$ protons. In ${ }^{13} \mathrm{C}$ NMR spectra, the spiro carbon atom displayed a signal at $\delta$ 81.0 and the amide and keto carbonyl carbon atoms

Table 3. Synthesis of spirooxindole derivatives (6a-e).

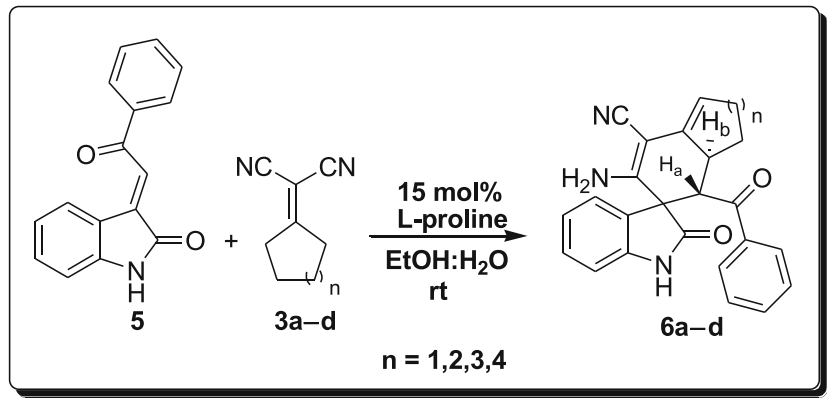

\begin{tabular}{|c|c|c|c|c|}
\hline Entry & Vinylogous malononitrile & Product & Time (h) & Yield $(\%)^{[a]}$ \\
\hline 1 & $3 \mathbf{b}$ & 6a & 3 & 83 \\
\hline 2 & 3a & $6 \mathrm{~b}$ & 2.5 & 80 \\
\hline 3 & $3 \mathrm{cc}$ & $6 c$ & 2 & 79 \\
\hline 4 & 3d & $6 d$ & 3.5 & 82 \\
\hline 5 & $3 e$ & $6 e$ & 4 & 80 \\
\hline
\end{tabular}

${ }^{[a]}$ Isolated yield after recrystallization from methanol 
resonated at $\delta 176.0$ and 200.5, respectively. The mass spectra also exhibited a distinguishing peak at $\mathrm{m} / \mathrm{z} 396$ $[\mathrm{M}+\mathrm{H}]^{+}$. The reaction was also performed using 2-(2,3dihydronaphthalen- $4(1 \mathrm{H})$-ylidene)malononitrile $\mathbf{3 e}$ as vinyl malononitrile to afford $\mathbf{6 e}$ in $80 \%$ yield.

\subsection{Pharmacology}

3.2a Antimicrobial activity: In the present study, antimicrobial activities of synthesized compounds were screened against bacteria (Bacillus subtilis MTCC 441, Micrococcus luteus MTCC 106, Enterobacter aerogenes MTCC 111, Staphylococcus aureus MTCC 96, Klebsiella pneumoniae MTCC 109, Proteus vulgaris MTCC 1771, Salmonella typhimurium MTCC 1251 and Staphylococcus aureus (MRSA-methicillin resistant) and fungi (Malassesia pachydermatis and Candida albicans) using in vitro disc diffusion method. Streptomycin was used as a positive control against bacteria and Ketoconazole was used as a positive control against fungi.

Results revealed that most of the synthesised compounds exhibited antimicrobial activities against Bacillus subtilis, Micrococcus luteus, Staphylococcus aureus, Klebsiella pneumoniae, Enterobacter aerogenes, Proteus vulgaris, Salmonella typhimurium, Staphylococcus aureus (MRSA-methicillin resistant), Malassesia pachydermatis and Candida albicans (see Supplementary information). Compounds $\mathbf{4 b}, \mathbf{4 c}, \mathbf{4 e}$, 4h, 6a, 6b, 6c and $6 \mathbf{d}$ have shown considerable antimicrobial activities. Compounds $\mathbf{4 d}, \mathbf{4 e}, \mathbf{4 h}, \mathbf{6 c}, \mathbf{6 d}$ show excellent activities more than the standard drug against the Gram-positive bacteria $S$. aureus. Among the compounds synthesized and tested for antimicrobial activity, $4 \mathbf{c}, \mathbf{4 h}$ and $\mathbf{6 b}$ exhibit significant antimicrobial activities and compound $\mathbf{4 h}$ has shown promising activity against both Gram-positive and Gram-negative bacteria.

3.2b Minimum inhibitory concentration: Minimum inhibitory concentration studies of the synthesized compounds were performed according to the standard reference methods for bacteria, filamentous fungi and yeasts. MIC values of active compounds against bacteria and fungi are given in Supplementary information. Significant MIC values were observed against Grampositive, Gram-negative bacteria and fungi. Compounds 4b, 4c, 4d, 4e, 4h, 6a, 6b, 6c, and 6d showed good antibacterial activity against bacteria at $1 \mathrm{mg} / \mathrm{disc}$ (see Supplementary information). Interestingly compounds 4e and $\mathbf{4 h}$ show promising antibacterial activity against $S$. aureus. Among all the compounds tested for minimum inhibitory concentration, $\mathbf{6 b}$ has shown significant MIC values against Enterobacter aerogenes, Proteus vulgaris and Salmonella typhimurium.

\section{Conclusion}

Thus, we have successfully established a new multicomponent domino reaction for the synthesis of polyfunctionalized spirocarbocycles from activated double bonds such as chalcones and vinylogous malononitriles. The spirocarbocycles were produced in a single step in excellent yields without involving tedious extraction and isolation procedures. The reaction brings forth a green protocol involving the usage of environmentally benign organocatalyst L-proline in ecofriendly solvent medium such as ethanol-water mixture. It also eliminates the use of hazardous solvents and expensive catalysts. The compounds were also screened for antimicrobial activities against four Gram-positive bacteria and Gram-negative bacteria and also against two fungi. Most of the compounds have found to exhibit significant antimicrobial activity of which $\mathbf{4 e}, \mathbf{4 h}$ and 6b have shown good activity and hence are promising candidates as antibacterial and antifungal agents.

\section{Supplementary information}

The electronic Supplementary information can be seen at www.ias.ac.in/chemsci.

\section{Acknowledgements}

SEK thanks the Council of Scientific and Industrial Research (CSIR), New Delhi, India for the research fellowship. We also thank Department of Chemistry, Indian Institute of Technology, Madras for X-ray single crystal analysis.

\section{References}

1. (a) Graaff C D, Ruijter E and Orru R V A 2012 Chem. Soc. Rev. 41 3969; (b) Enders D, Uttl M R M H, Grondal C and Raabe G 2006 Nature 441 861; (c) Tietze L F 1996 Chem. Rev. 96 115; (d) Li G, Wei H X and Kim S -H, Carducci M D 2001 Angew. Chem. Int. Ed. 404277

2. (a) Jiang B, Tu S J, Kaur P, Wever W and Li G G 2009 J. Am. Chem. Soc. 131 11660; (b) Jiang B, Li C, Shi F, Tu S J, Kaur P, Wever W and Li G G 2010 J. Org. Chem. 75 2962; (c) Ivanov A S 2008 Chem. Soc. Rev. 37 789; (d) Padwa A 2009 Chem. Soc. Rev. 38 3072; (e) Padwa A and Bur S K 2007 Tetrahedron 635341

3. Wang J, Li Q, Qi C, Liu Y, Ge Z and Li R 2010 Org. Biomol. Chem. 84240

4. Young-Won C, Angela S, Bao-Ning S, Qiuwen M, HeeByung C, Soedarsono R, Leonardus K, Agus R, Norman F, Steven S and Douglas K 2008 J. Nat. Prod. 3390

5. Van der Sar S, Blunt J and Munro M 2006 Org. Lett. 8 2059 
6. Krzysztof K, Jolanta O and Malgorzata D 2008 Eur. J. Med. Chem. 4353

7. (a) Chande M S, Verma R S, Barve P A, Khanwelkar R R, Vaidya R B and Ajaikumar K B 2005 Eur. J. Med. Chem. 40 1143; (b) Pawar M J and Burungale A B, Karale B K 2009 ARKIVOC (XIII) 97; (c) Thadhaney B, Sain D, Pernawat G and Talesara G L 2010 Indian J. Chem. 49B 368.

8. (a) Nicholas G M, Eckman L L and Newton G L 2003 Bioorg. Med. Chem. 11 601; (b) Suenaga K, Araki K and Sengoku T 2001 Org. Lett. 3 527; (c) Trost B M and Brennan M K 2009 Synthesis 3003; (d) Heathcock C H, Graham S L, Pirrung M C, Plavac F and White C T 1983 In Spirocyclic systems in the total synthesis of natural products; J Simon (ed) (New York: John Wiley and Sons) p. 264; (e) Sanchez-Larios E, Holmes J M, Daschner C L and Gravel M 2010 Org. Lett. 125772

9. (a) Liu T L, He Z L, Tao H Y, Cai Y P and Wang C J 2011 Chem. Commun. 47 2616; (b) Trost B M, Cramer $\mathrm{N}$ and Silverman S M 2007 J. Am. Chem. Soc. 129 12396; (c) Liu T -L, Xue Z-Y, Tao H -Y, Wang C-J 2011 Org. Biomol. Chem. 9 1980; (d) Pellissier H 2007 Tetrahedron 633235

10. (a) Tamao K, Nakamura K, Ishii H, Yamaguchi S and Shiro M 1996 J. Am. Chem. Soc. 118 12469; (b) Mikami K, Yusa Y, Hatano M, Wakabayashi K and Aikawa K 2004 Chem. Commun. 98; (c) Mikami K, Yusa Y, Hatano M, Wakabayashi K and Aikawa K 2004 Tetrahedron 60 4475; (d) Hatano M, Terada M and Mikami K 2001 Angew. Chem. Int. Ed. 40 249; (e) Hatano M and Mikami K 2003 Org. Biomol. Chem. 1 3871; (f) Wu Q -F, He H, Liu W-B and You S-L $2010 \mathrm{~J}$. Am. Chem. Soc. 132 11418; (g) Teng X, Cefalo D R, Schrock R R and Hoveyda A H 2002 J. Am. Chem. Soc. 12410779

11. (a) Rios R 2012 Chem. Soc. Rev. 41 1060; (b) Kotha S, Deb A C and Kumar R V 2005 Bioorg. Med. Chem. Lett. 15 1039; (c) Kotha S and Deb A C 2008 Indian J. Chem. Sect. B: Org. Chem. Incl. Med. Chem. 47 1120; (d) Schobert R and Gonzalez J M U 2005 Tetrahedron Lett. 463657

12. (a) Kende A S and Koch K 1986 Tetrahedron Lett. 27 6051; (b) Miranda L D and Zard S Z 2002 Org. Lett. 4 1135; (c) Chikaoka S, Toyao A, Ogasawara M, Tamura $\mathrm{O}$ and Ishibashi H $2003 \mathrm{~J}$. Org. Chem. 68 312; (d) Inui M, Nakazaki A and Kobayashi S 2007 Org. Lett. 9 469; (e) Gonzalez-Lopez de Turiso F and Curran D P 2005 Org. Lett. 7 151; (f) Lanza T, Leardini R, Minozzi M, Nanni D, Spagnolo P and Zanardi G 2008 Angew. Chem. Int. Ed. 489439
13. (a) Davis R L, Leverett C A, Romo D and Tantillo D J 2011 J. Org. Chem. 76 7167; (b) Sonia A, Sar V, Blunt J W and Munro M H G 2006 Org. Lett. 82059

14. (a) Beccalli E M and Marchesini A 1987 J. Org. Chem. 52 1666; (b) Attanasi O A, Filippone P, Fiorucci C and Mantellini F 2000 Chem. Lett. 29 984; (c) Risitano F, Grassi G, Foti F, Nicolo F and Condello M. 2002 Tetrahedron 58 191; (d) Chande M S, Verna R S, Barve P A, Khanwelkar R R, Vaidya R B and Ajaikumar K B 2005 Eur. J. Med. Chem. 401143

15. (a) Nicholas G M, Eckman L L and Newton G L 2003 Bioorg. Med. Chem. 11 601; (b) Suenaga K, Araki K and Sengoku T 2001 Org. Lett. 3 527; (c) Winfred G B, Rutger M and Fieseler F 2000 J. Org. Chem. 65 8317; (d) Patrizia C, Carmela D and Ernesto F 1999 J. Nat. Prod. 62 590; (e) Metwally K A, and Dukat M 1998 J. Med. Chem. 41 5084; (f) Barbara C M, Potts D and John F 1991 J. Am. Chem. Soc. 1136321

16. (a) Babu T H, Karthik K and Perumal P T 2010 Synlett 1128; (b) Babu T H, Sujeet P, Muralidharan D and Perumal P T 2010 Synlett 2125; (c) Babu T H, Abragam A J, Muralidharan D and Perumal P T 2010 Tetrahedron Lett. 51 994; (d) Babu T H, Perumal, P T 2010 Synlett 341

17. Balachandran C, Duraipandiyan, V, Al-Dhabi N A, Balakrishna K, Kalia N P, Rajput V S, Khan I A and Ignacimuthu S 2012 J. Microbiol. 52676

18. Duraipandiyan V and Ignacimuthu S 2009 J. Ethnopharmacol. 123494

19. Clinical and Laboratory Standards Institute (CLSI) 2008 Reference method for broth dilution antifungal susceptibility testing of filamentous fungi; Approved standard second edition. CLSI document M38-A2 (ISBN 156238-668-9). Clinical and Laboratory Standards Institute, 940, West valley Road, Suite 1400, Wayne, Pennsylvania 19087-1898 USA

20. National Committee for Clinical Laboratory Standards. Reference method for broth dilution antifungal susceptibility testing of yeasts: proposed standard, NCCLS, 2002 M27-A2

21. The EtOH: $\mathrm{H}_{2} \mathrm{O}$ mixture was tried in order to effect easier precipitation of the product

22. Crystallographic data for compound $\mathbf{4 g}$ in this paper have been deposited with the Cambridge Crystallographic Data centre as supplemental publication no. CCDC- 905942. Copies of the data can be obtained, free of charge on application to CCDC, 12 Union Road, Cambridge CB2 1EZ, UK (fax: +44 01223336033 or email: deposit@ccdc.cam.ac.uk) 